\title{
Performance and Emission Characteristics of Cashewnut Shell Liquid as Alternate Fuel with Five Hole Nozzle
}

\author{
Sangeetha Krishnamoorthi, L.Prabhu, Sakthikumar R, Prabakaran K, Pradeep M
}

\begin{abstract}
Natural elements such as plants, vegetables, and reusable materials are the main sources of biodiesel. Harmful chemicals that can affect the environment in a worse condition is not produced by this biodiesel which affects the atmosphere. Alternative sources for energy has been searched by the people in an increasing manner in the recent days. The paper deals with the use of Cashew nut shell liquid as an alternative fuel which is obtained from cashew industry as a by product. Fuel is injected into the engine as a fine sprayer through the injection nozzle. To spray diesel fuel in the cylinder an injector nozzle is fixed at the top with lot of holes. The injector nozzle is used to mix the fuel and airand is sprayed at a high pressure. As the spray cone angle is large in the multi hole injector nozzles diesel can be sprayed in a better way to obtain a uniform mixture.
\end{abstract}

Keyword: CNSL, Five Hole Nozzle

\section{INTRODUCTION}

Production and export of cashew is done in a large scale in our country.Damodhar (2014) studied that the cashew nut shell contains $25-30 \%$ dark reddish brown viscous phenolic liquid known as Cashew nut shell liquid and is a by product of the cashew industry. From Cashew nut shell the CNSL is obtained in a number of different methods. Open pan roasting, hot oil roasting, cold extraction, solvent extraction and pyrolysis process are the different methods of extracting the CNSL oil from the byproduct. There is a difference in the composition of certain chemical properties when the oil is produced by using different methods.Banapurmath (2008) studied that the high viscosity of vegetable oils lead to problem in pumping and spray characteristics and the inefficient mixing of vegetable oils with air contributes to incomplete combustion. Transesterification process is one in which the biodiesel is obtained from the raw vegetable oil. In the absence of air or nitrogen thermal energy is applied and due to this a chemical change is obtained which is known as pyrolysis method of obtaining biodiesel. Cardanol which is of $78 \%$,cardol which is of $8 \%$ and polymeric material of $2 \%$ are the compositions obtained in the distillation process of CNSL.Mallikappa , explained that the engine deposits,

Revised Manuscript Received on September 22, 2019

* Correspondence Author

Sangeetha Krishnamoorthi -Associate Professor, Department of Mechanical Engineering, Aarupadai Veedu Institute of Technology, Vinayaka Mission Research Foundation, Deemed to be University sangeethas@gmail.com

L.Prabhu - Professor, Department of Mechanical Engineering,

Aarupadai Veedu Institute of Technology, Vinayaka Mission Research Foundation, Deemed to be University prabhu@avit.ac.in

Sakthikumar R,Prabakaran K, Pradeep M, UG Scholars, Aarupadai Veedu Institute of Technology, Vinayaka Mission'S Research Foundation injector plugging, or lube oil gelling are the problems caused when the pure oils are used directly in the diesel engines. After this pyrolysis process the Cardanol which is of dark brown colour, without can modifications can be used in the CI Engines.Damodhar J (2014) studied that the Indian cashew nut shell steam roasted shells as well raw cashew nut shells and their yields at different solute to solvent ratios. This enables optimum solute to solvent ratios for extraction of CNSL. In this work the Biofuel which was obtained by the transesterification process was blended with diesel and by using a five hole nozzle the various properties has been compared in the compression ignition engines.

\section{EXPERIMENTAL SET UP \& INJECTION NOZZLE}

One of the main concern about the VCR engine is that it may perform in an different manner when using a biodiesel in the place of diesel. The performance tests were conducted on a computerised VCR Engine Setup with 1 Cylinder, 4 stroke, Diesel Engine, Kirolskar made, and water cooled, which operates at a speed of $1500 \mathrm{rpm}$ and a power $3.5 \mathrm{~kW}$. The specifications of the engine isgiven in the table 1 below.

Table 1: Specifications of the engine

\begin{tabular}{|c|c|c|}
\hline S. No. & Parameters & Specification \\
\hline 1 & Engine & 4 Stroke, Single Cylinder, Constant Speed, Water Cooled Diesel Engine \\
\hline 2 & Make & Kirloskar \\
\hline 3 & BHP & $3.5 \mathrm{~kW} @ 1500$ RPM \\
\hline 4 & Stroke Length & $110 \mathrm{~mm}$ \\
\hline 5 & Compression Ratio & $12: 1$ to $18: 1$ \\
\hline 6 & Connecting Rod Length & $234 \mathrm{~mm}$ \\
\hline 7 & Dynamometer Type & Eddy Current Type with Loading Unit \\
\hline
\end{tabular}

The injection timing and atomization of fuel droplets are effectively controlled by the fuel injection system. Nowadays the injection systems are provided with efficient electronic systems which can handle even very high injection pressures. Nozzle is a device used to control the characteristics and direction of the fluid and is shown in the fig. 1 below.In this paper a nozzle with 5 holes has been used and the performance and emission characteristics are tested. The fuel injection performance is important for low emission combustion. [1] In the case of agricultural applications, fuels that can be produced in rural areas in a decentralized manner, near the consumption points will be used frequently.

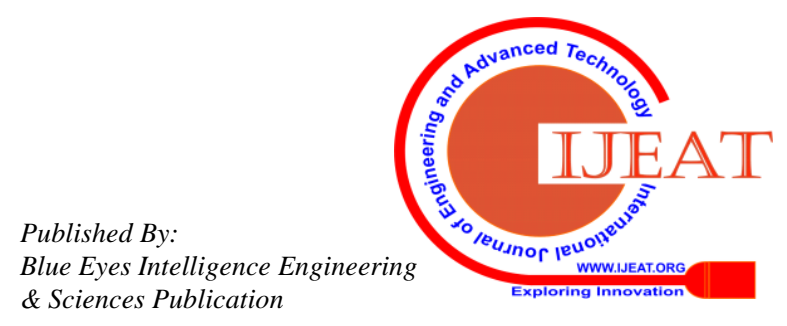



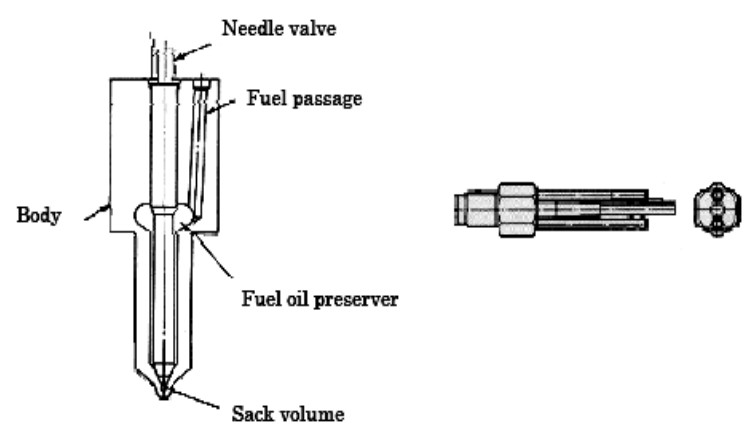

Fig.1 Schematic of nozzle

\section{RESULTS AND DISCUSSION}

The (BSFC) Brake specific fuel consumption along with the Brake power by using a five hole nozzle is shown in the fig. 2.The ratio of power produced for the fuel consumed is given by the Brake specific fuel consumption. The efficiency of IC engines with shaft output is measured by the Brake specific fuel consumption.The BSFC for B20 is $0.39 \mathrm{~kg} / \mathrm{kwhr}$ and the $\mathrm{BSFC}$ for B40 is $0.37 \mathrm{~kg} / \mathrm{kw} \mathrm{hr}$ and the BSFC for B80 is 0.41 $\mathrm{kg} / \mathrm{kw} \mathrm{hr}$.The BSFC for diesel is $0.27 \mathrm{~kg} / \mathrm{kw} \mathrm{hr}$.

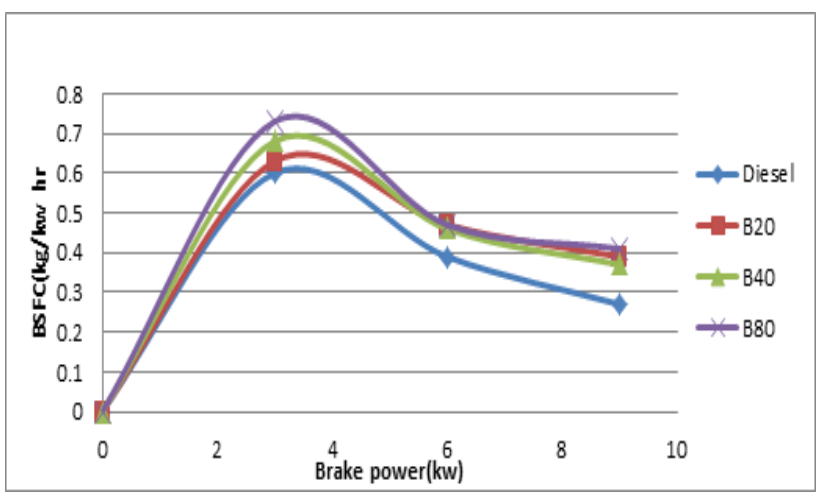

Fig 2 BSFC VS BP

Fig 3 shows the plot of Brake thermal efficiency with Brake power. Brake thermal efficiency tells us how effectively the mechanical energy is produced by the heat from the fuel. VedatKaraman [2] revealed that the higher compression ratio results with higher brake thermal efficiency (BTHE) and thus lower specific fuel consumption (SFC). The author studied the subject with some critical performance criterias such as brake thermal efficiency, specific fuel consumption, and emissions of carbon monoxide, carbon dioxide, hydrocarbons, nitrogen oxides and smoke opacity with Jatropha methyl ester as fuel. The BTE for B20 is 23.3 $\mathrm{kg} / \mathrm{kwhr}$ and the BTE for B40 is $24.5 \mathrm{~kg} / \mathrm{kw} \mathrm{hr}$ and the BTE for B80 is $21 \mathrm{~kg} / \mathrm{kw} \mathrm{hr}$. The BTE for diesel is $31.7 \mathrm{~kg} / \mathrm{kw} \mathrm{hr}$. Fig 4 shows the plot of Hydrocarbon emissions with the brake power. Hydrocarbon emissions occur when air fuel mixture has not burned properly during the combustion process.Broatch et al [3] studied that most of the $\mathrm{HC}$ and $\mathrm{CO}$ emissions from automotive diesel engine are produced during the engine warm up period and are caused by difficulties in obtaining stable and efficient combustion under these conditions. If the amount of $\mathrm{HC}$ emissions is reduced there may be a good improvement in the efficiency and performance of the engine. The HC for B20 is $23 \mathrm{~kg} / \mathrm{kw} \mathrm{hr}$ and the $\mathrm{HC}$ for $\mathrm{B} 40$ is 9 is $\mathrm{kg} / \mathrm{kw} \mathrm{hr}$ and the $\mathrm{HC}$ for $\mathrm{B} 80$ is 15 $\mathrm{kg} / \mathrm{kw} \mathrm{hrThe} \mathrm{HC}$ for diesel is $6 \mathrm{~kg} / \mathrm{kw} \mathrm{hr}$.

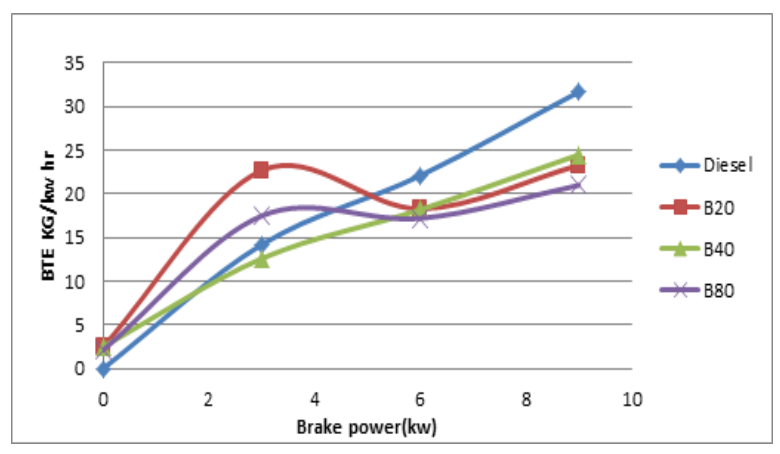

Fig 3 BTE VS BP

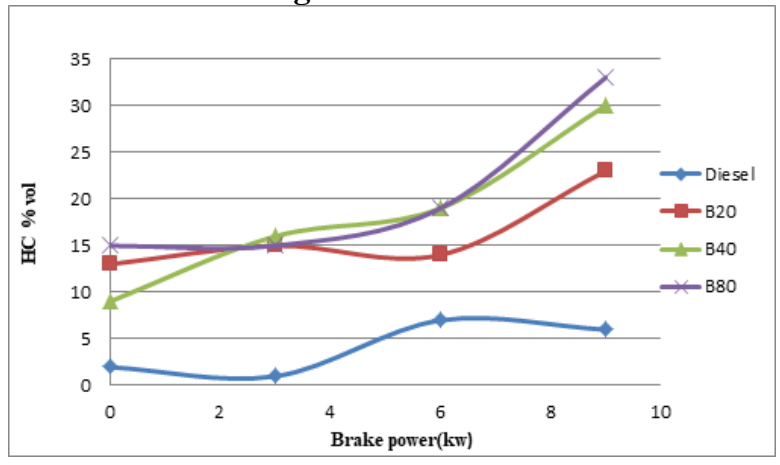

Fig 4 HC VS BP

Fig 5 shows the plot of Carbon monoxide emissionswith the Brake power. The main by product of incomplete combustion is Carbon monoxide. $\mathrm{CO} 2$ accessible in the air will be caught by seas, meadows, they are insufficient to control $\mathrm{CO} 2$ present in the climate totally. Likewise progresses in motor and vehicle innovation consistently to lessen the discharge from motor fumes are not adequate to decrease the $\mathrm{HC}$ and $\mathrm{CO}$ emanation. The $\mathrm{CO}$ for $\mathrm{B} 20$ is $0.17 \mathrm{~kg} / \mathrm{kwhr}$ and the $\mathrm{CO}$ for $\mathrm{B} 40$ is $0.13 \mathrm{~kg} / \mathrm{kw} \mathrm{hr}$ and the $\mathrm{CO}$ for $\mathrm{B} 80$ is $0.13 \mathrm{~kg} / \mathrm{kw}$ $\mathrm{hr}$.The CO for diesel is $0.02 \mathrm{~kg} / \mathrm{kw} \mathrm{hr}$.

Fig 6 shows the plot of Carbon dioxide emissions with Brake power.The carbon which is obtained from the fuel Is fully oxidized and due to which the $\mathrm{CO} 2$ emissions are more closer to the neat diesel fuel. It is noted that $\mathrm{CO} 2$ emissions is lower for B20 CNSL oil with effect to the neat diesel. The CO2 for $\mathrm{B} 20$ is $1.4 \mathrm{~kg} / \mathrm{kwhr}$ and the $\mathrm{CO} 2$ for $\mathrm{B} 40$ is $1.5 \mathrm{~kg} / \mathrm{kw} \mathrm{hr}$ and the $\mathrm{CO} 2$ for $\mathrm{B} 80$ is $1.6 \mathrm{~kg} / \mathrm{kw}$ hr.The $\mathrm{CO} 2$ for diesel is 1 $\mathrm{kg} / \mathrm{kw} \mathrm{hr}$.

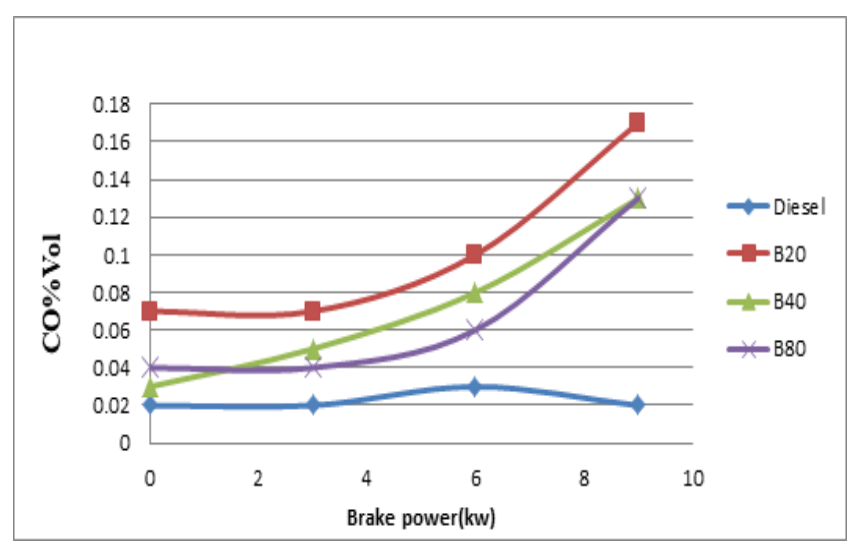

Fig 5 CO VS BP 


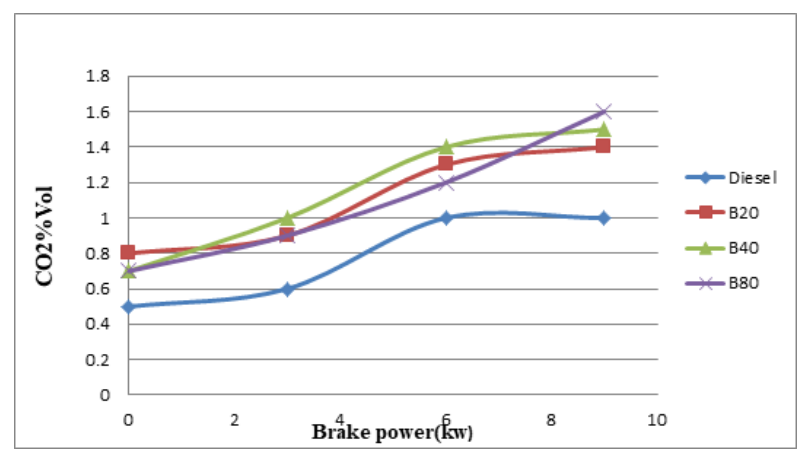

Fig 6 CO2 VS BP

Fig 7 shows the plot of NOx emissions with Brake power. As NOx value increase with the increasing load here also the NOx emissions are slightly higher for all the blends. The NOx value of B20 is found to be closer to the neat diesel value.

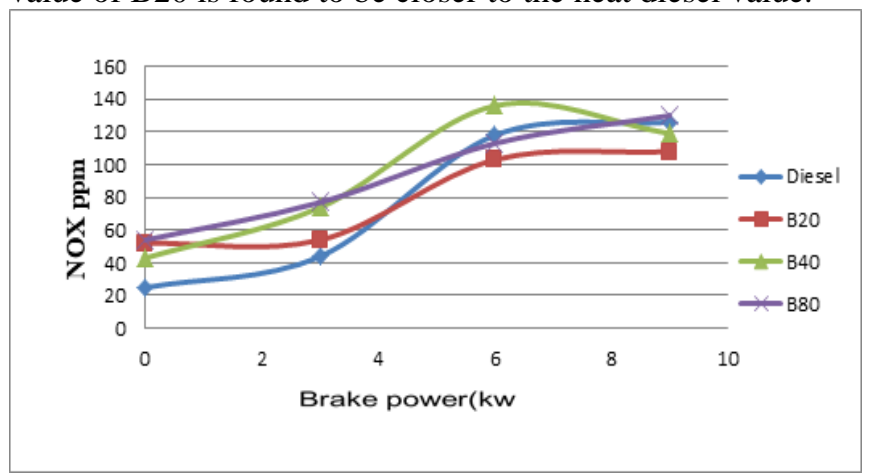

Fig 7 NOX VS BP

\section{CONCLUSIONS}

The Brake specific fuel consumption value was found to be increased for the 5 hole nozzle for higher blends and can be in a acceptable level for the lower blends. The Brake thermal efficiency for the B40 with a five hole nozzle shows better results when compared with diesel fuel. The hydrocarbon emissions also are in an acceptable level for the blend B40 comparing with the neat diesel. Carbon monoxide emissions which occurs due to the incomplete combustion is almost high for all the CNSL blends and the Blend B40 is nearer to the diesel fuel. The Carbondioxideemissions are reduced by using the 5 hole nozzle and the values are almost close to the neat diesel fuel. The NOx emissions always show an increase for the biodiesel and so it is concluded that, when compared to the other blends the blend B40 values of CNSL when using a five hole nozzle shows a better results and this can be used as an alternate for the diesel fuel.

\section{REFERENCES}

1. DamodharGarka J. and Ramesh Bhande S. (2014) "Review on extraction and isolation of cashew nut shell liquid", International Journal of Innovations in Engineering Research and Technology(IJIERT), Vol.1.Nov. (2014)

2. N.R. Banapurmath "Performance and emission characteristics of a DI compression ignition engine operated on Honge, Jatropha and sesame oil methyl esters" Elsevier Renewable Energy., Vol., 33 (2008) pp.1982-1988

3. VedatKaraman "Calculation and Optimizing of Brake Thermal Efficiency of Diesel Engines Based on Theoretical Diesel Cycle Parameters" International Journal Of Engineering Technologies Vol.2, No.3, 2016

4. A Broatch "Measurement of hydrocarbon and carbon monoxide emissions during the starting of automotive DI Diesel engines"
International journal of automotive technology April 2008 Vol 9 Issue 2 Pp 129-140

5. $\mathrm{K}$ N Balan "Analysis of $\mathrm{CO} 2, \mathrm{CO}$ and $\mathrm{HC}$ emission reduction in automobiles Frontiers in Automobile and Mechanical Engineering” IOP Publishing IOP Conf. Series: Materials Science and Engineering 197 (2017) 012012

6. M. Saravanakumar "Emission Characterristics of Biodiesel Derived From Used Cooking Oil Blended With Diesel In The Presence of Potassium Hydroxide (KOH) Catalyst As Alternative Fuel For Diesel Engines" Journal of Rasayan J. Chem., Volume 11 No.1 , pp. 372-377, 2018

7. M. Prabhahar, S. Sendilvelan and J. Francis Xavier"Effect of Dimethoxy-Methane $\left(\mathrm{C}_{3} \mathrm{H}_{8} \mathrm{O}_{2}\right)$ On Combustion Characteristics Of A Direct Injection Diesel Engine With Variable Compression Ratio Fuelled With Biodiesel Blends With Diesel $\left(\mathrm{C}_{10.8} \mathrm{H}_{18.7}\right)$ " Journal of Oriental Journal of Chemistry Vol 33, No 6, 2017

8. M. Prabhahar, S. Sendilvelan, S. Prakash and M. Saravanakumar "Investigation of Pine Oil Methyl Ester Blends With Diesel On A Compression Ignition Engine To Control Oxides of Nitrogen And Soot Particles" Journal of Rasayan J. Chem., Volume 10 No.4, pp. 1075-1079, 2017

9. R. Senthil Kumar "Experimental Investigation of Injectors Nozzle Hole on CI engine Using Jatropha Oil as Bio-fuel" International Journal of Scientific Research Engineering \& Technology (IJSRET), ISSN 2278 - 0882 Volume 3, Issue 8, November 2014 